\title{
THE ASSOCIATION BETWEEN NEED OF SUCCESS, DIET, SOCIAL POSITIONING AND CHD RISK
}

\author{
G. Sarov ${ }^{*}$, T. Todorova ${ }^{2}$, J. Georgieva ${ }^{2}$ \\ ${ }^{1}$ Dept. Medical Sociology, Faculty of Medicine, Trakia University, Stara Zagora, Bulgaria \\ ${ }^{2}$ Student at Faculty of Medicine, Trakia University, Stara Zagora, Bulgaria
}

\begin{abstract}
INTRODUCTION: It has been established, that some personal traits associate with increased risk of coronary heart disease (CHD). The purpose of this article is to find out the associations between the need of success, social circumstances, diet preferences and CHD risk. METHOD: We interviewed 600 people of both genders aged between 19 and 75. Of them, 46 declare that the most valuable thing in their life is pleasure (hedonists), and 66 think that success is of higher importance (n Ach). RESULTS: $\mathrm{n}$ Ach significantly more often declared that their income is not enough for optimal satisfaction of their needs $(\mathrm{p}<0,05)$. Hedonists evaluate themselves more often as highly physically active at working place $(p<0.05)$ and home $(p<0.05)$. Hedonists were more likely to spend their free time with friends at parties $(\mathrm{p}<0.05)$, to consume meat daily $(\mathrm{p}<0.05)$, and fruits $(\mathrm{p}<0.05)$, whereas $\mathrm{n}$ Ach have a preference for pork meat $(p<0.05)$ and consume more often milk and energy drinks $(p<0.001)$. CONCLUSION: The different attitudes to life-style are associated with significant differences in eating habits, physical activity and social security. The need of success (typical features of type A) associates with social circumstances and diet that may increase CHD risk.
\end{abstract}

Key words: personality, social context, ischemic heart disease, risk factors, $\mathrm{n}$ Ach, hedonism

\section{INTRODUCTION}

One of the most important problems in medicine is risky behavior. In contemporary society, unhealthy diet and psycho-emotional stress are major risk factors for coronary heart disease. It is well-known that type A personality (1) associates with higher CHD risk than Type B (2). Type A behavior is characterized by strong competitive drive, always in the press of deadlines. They tend to choose very challenging tasks (3) and suffer from hurry sickness $(4,5)$, in case of failure they are more likely to blame themselves rather than the situation $(6,7)$, and to express hostility toward others under stress $(8,9)$. There is an assumption that the main trait of type $\mathrm{A}$ is their strong need to control events $(10,11)$ and refusing to give up the control to another one, even when he/she is doing better (12). Type A persons are more likely to react excessively in physiological sense (increasing blood pressure) $(13,14)$ and to ignore signals of physical Distress $(15,16)$ when working on difficult tasks. They have elevated serum cholesterol

\footnotetext{
* Correspondence to: Georgi Sarov, Trakia

University, 11 Armeiska Str, Stara Zagora 6000,

Bulgaria,gsarov@yahoo.com,tel.+359

888175411
}

(1) and catecholamine levels (17). Their aspirations to achievements makes them socially successful at younger age (18) and provides better working positions (19), which increases their well-being in youth, but their life satisfaction in old age is worse. The pathogenic role of type A is mainly explained by the influence of negative emotions (anger, aggression) on serum cholesterol levels regardless of diet (20). It was also found that the type A is associated with a significant increase of alcohol consumption compared with a non-type A (21).

In psychology there is a concept need of achievements ( $\mathrm{n}$ Ach) that has no medical interpretation to date. The high $\mathrm{n}$ Ach people are highly motivated to act for self-confidence (22). If the benefit is both material and social low and high $\mathrm{n}$ Ach show the same motivation and perform equally well. High $\mathrm{n}$ Ach are willing to work for social purposes as hard as for their own (23), but only if they are entitled to independent decisions (24). In high-risk situation high $\mathrm{n}$ Ach prefer moderate risk, and low $\mathrm{n}$ Ach - low or high risk (25).

From a medical point of view both high $\mathrm{n}$ Ach and type A are highly motivated to act, that 
suggests psycho-emotional stress and metabolic mobilization. Therefore the study of health-related behavior and social positioning of high $n$ Ach can show whether the need of achievements could have pathogenic contribution to CHD and explain, at least in part, the pathogenesis of type A behavior.

As the main purpose of the study is the pathogenic effect of mental mobilization we compare $\mathrm{n}$ Ach with the people that declare highest value of pleasure (hedonists) with presumption that such drive would induce lowest level of mobilization, as pleasures have a relaxing effect. Moreover hedonists are much closer to the concept type $\mathrm{B}$, which is the true counterpoint of type A, but not non- Type A people. Type $\mathrm{A}$ and Type $\mathrm{B}$ are the two poles of a continuum, in the middle of which are people who are neither type A nor type B, so the use of non-Type $A$ as a comparison group of is Type A is methodologically wrong.

\section{METHODS}

We used a questionnaire with self-assessment questions, exploring diet, personal attitudes to success and pleasure and social circumstances. 600 people of both genders aged 19 to 75 years were interviewed by students of Medical Faculty, Stara Zagora at specially equipped stations on the streets (random selection). Of them 66 declared that the most important thing in life is success ( $\mathrm{n} \mathrm{Ach)}$ and 46 - the most important thing in life is pleasure (hedonists). These two groups were compared for the dietary preferences and social circumstances. Percentage distribution, $\chi 2$ test and t-test were uses as statistical methods.

\section{RESULTS}

There were no significant differences (t-test ) between the two groups in age, weight, height, daily consumption of alcohol but hedonists were found to have a higher BMI $(26,19 \pm 5,77)$ than $n$ Ach $(23,69 \pm 5,66 ; p<0.05)$. $\mathrm{n}$ Ach were more likely to be males $(69,7 \pm 5,66 \%)$ than hedonists $(47,8 \pm 7,37 \%$; $\mathrm{p}<0.05)$, among which gender differ not significantly ( $\chi 2$ test).

Compared to $\mathrm{n}$ Ach hedonists significantly more often consume meat, cheese, fruit and canned fruit (Table 1). Consumption of milk, dairy products and energizing drinks is significantly more frequent in $\mathrm{n}$ Ach, while hedonists consume these products very rarely. Public sector employees are significantly more and private sector employees - significantly less in $\mathrm{n}$ Ach than in hedonists (Table 2). $\mathrm{n}$ Ach declared significantly less optimal material satisfaction and significantly more limited one. Physical activity at working place and leisure time is less typical for $\mathrm{n}$ Ach than for hedonists as well as parties with friends.

\section{CONCLUSIONS}

We interpret the results of this study, in the context of understanding that the need for achievement is an important feature of Type A behavior. Data showed that $\mathrm{n}$ Ach material satisfaction is limited, and they are less likely to be private employees and more likely to be public sector employees, which corresponds to $\mathrm{n}$ Ach description in the literature $(22,23,25)$. n Ach were not associated with heavy physical work at working place or leisure time, probably due to the fact that success in modern times is achieved primarily with intellectual rather than physical efforts, but this generates a risk of immobilization, which is a metabolic risk factor. On the other hand, $\mathrm{n}$ Ach are significantly less likely to communicate with friends in their leisure time, probably due to lack of time, but they miss the opportunity to relax by meeting friends and thus to reduce psycho-emotional stress. Immobilization and social isolation suggest that the need of achievement tends to produce unfavorable for health social positioning.

n Ach prefer more easily digestible sources of cholesterol (milk and milk products) in combination with reduced acceptance of fruits (which are known to contain pectin that allow the elimination of cholesterol from the body). Furthermore, they use more often energizing drink, which is known to stimulate catecholamine production and mobilize metabolism, generating a burst of energy. If recall that the development of the nervous system is primarily a growth of dendrites and axons, ie membranes, and the main purpose and the largest pool of cholesterol in the body is the membranes, we can speculate that the need for success creates a need for cholesterol retention. Meat also contains cholesterol, but it is more difficult to digest and loads digestive system and reduces the blood supply to the brain, and the ability to think precisely, necessary for making correct decisions. The frequent use of energizing drink probably contributes to the further increase in the productivity of thinking.

Hedonists, have higher physical activity and probably gain the energy they need from meat and fruits, and as the physical activity energizes the psyche, they do not need of energizing drinks. As a result of this dietary combination, they have higher BMI, but lower risk of cholesterol retention and catecholamine overstimulation. So, we found, without being able to explain exactly how, that need of achievement creates dietary risk for cholesterol 
retention and increased catecholamine levels (both CHD risk factors), while hedonism creates dietary risk for body overweight. Thus, the need of achievements can explain at least in part the pathogenicity of type A behavior.

The higher incidence rate of male gender among $\mathrm{n}$ Ach, we found, corresponds with the assumption that women avoid achievements fearing the loss of femininity $(26,27,28)$ As the male gender is a major risk factor for CHD, one of the mechanisms responsible for this might be the higher need for achievement among men.

In conclusion, as the need of achievements is a component of Type A behavior and more typical for males, it is reasonable to suppose that it contributes for the CHD risk not only via emotional stress but also by specific changes in dietary preferences.

Table 1. Dietary preferences of the respondents

\begin{tabular}{llll}
\hline & n Ach & hedonists & \\
& $\% \pm$ SE & $\% \pm$ SE & $\mathrm{p}<$ \\
\hline Meat and meat products-daily & $21,21 \pm 5,03$ & $39,13 \pm 7,2$ & 0,05 \\
Cheese-daily & $19,7 \pm 4,9$ & $50 \pm 7,37$ & 0,001 \\
Fruit-daily & $15,15 \pm 4,41$ & $34,78 \pm 7,02$ & 0,05 \\
Canned fruits - several times a week & $10,6 \pm 3,8$ & $28,26 \pm 6,64$ & 0,05 \\
Coca-Cola - weekly & $4,54 \pm 2,56$ & $17,39 \pm 5,59$ & 0,05 \\
Milk - rarely or never & $19,69 \pm 4,9$ & $43,47 \pm 7,31$ & 0,01 \\
Milk and milk products - several times a week & $28,78 \pm 5,57$ & $8,7 \pm 4,15$ & 0,01 \\
Energy drinks - several times a week & $13,64 \pm 4,22$ & $2,17 \pm 2,15$ & 0,05 \\
Pork - weekly & $43,94 \pm 6,11$ & $21,74 \pm 6,08$ & 0,05 \\
\hline
\end{tabular}

Table 2. Social circumstances of the respondents

\begin{tabular}{llll} 
& n Ach & hedonists & \\
& $\% \pm$ SE & $\% \pm$ SE & p $<$ \\
\hline employment - in private enterprise & $25,75 \pm 5,38$ & $54,34 \pm 7,34$ & 0,01 \\
employment - public service & $39,39 \pm 6,01$ & $26,08 \pm 6,47$ & 0,01 \\
material satisfaction - optimal & $7,58 \pm 3,26$ & $28,26 \pm 6,64$ & 0,01 \\
material satisfaction - limited & $34,84 \pm 5,87$ & $17,39 \pm 5,59$ & 0,05 \\
physical activity at work - heavy & $13,64 \pm 4,22$ & $30,43 \pm 6,78$ & 0,05 \\
physical activity at work - almost no & $19,7 \pm 4,9$ & $6,52 \pm 3,64$ & 0,05 \\
physical activity in leisure time - daily & $25,76 \pm 5,38$ & $47,83 \pm 7,37$ & 0,05 \\
physical activity in leisure time - weekly & $31,82 \pm 5,73$ & $15,21 \pm 5,3$ & 0,05 \\
party with friends - several times a week & $18,18 \pm 4,75$ & $34,78 \pm 7,02$ & 0,05 \\
party with friends - less than once per week & $46,96 \pm 6,14$ & $10,86 \pm 4,59$ & 0,001 \\
\hline
\end{tabular}

\section{REFFERENCES}

1. Friedman, M. and Rosenman R.H. Type A behavior and your heart. London: Wildwood House, 1974.

2. Rosenman, R. H., Brand R.J., Jenkins C.D., Friedman, M., Straus, R., and Wurm, M. Coronary heart disease in Western Collaborative Group Study. Final follow-up experience of $81 / 2$ years. Journal of the American Medical Association, 233: 872877, 1975

3. Ortega, D. M., and Pipal, J. E. Challenge seeking and the Type A coronary-prone behavior pattern. Journal of Personality and Social Psychology, 46: 1328ᄀ1334, 1984

4. Glass, D. C. Behavior patterns, stress, and coronary disease. Hillsdale, NJ: Erlbaum. 1977
5. Matthews, K. A. Psychological perspectives on the Type A behavior pattern. Psychological Bulletin, 91: 293-323, 1982.

6. Musante, L., MacDougall, J. M., and Dembroski, T. M. The Type A behavior pattern and attributions for success and failure. Personality and Social Psychology Bulletin, 10: 544-553, 1984.

7. Rhodewalt, F. Self-involvement, selfattribution, and the Type A coronary-prone behavior pattern. Journal of Personality and Social Psychology, 47: 662-670, 1984.

8. Carver, C. S., and Glass, D. C. Coronaryprone behavior pattern and interpersonal aggression. Journal of Personality and Social Psychology, 36: 361-366, 1978.

9. Strube, M. J., Turner, C. W., Cerro, D., Stevens, J., and Hinchey, F. Interpersonal aggression and the Type A coronary-prone 
behavior pattern: A theoretical distinction and practical implications. Journal of Personality and Social Psychology, 47: 839-847, 1984.

10.Brunson, B. I., and Matthews, K. A. The Type A coronary-prone behavior pattern and reactions to uncontrollable stress: An analysis of performance, strategies, affect, and attributions during failure. Journal of Personality and Social Psychology, 40: 906-918, 1981.

11.Miller, S. M., Lack, E. R., and Asroff, S. Preference for control and the coronaryprone behavior pattern: "I'd rather do it myself." Journal of Personality and Social Psychology, 49: 492-499, 1985.

12.Strube, M. J., and Werner, C. Relinquishment of control and the Type A behavior pattern. Journal of Personality and Social Psychology, 48: 688-701, 1985.

13.Holmes, D. S., McGilley, B. M., and Houston, B. K. Task-related arousal of Type A and Type B persons: Level of challenge and response specificity. Journal of Personality and Social Psychology, 46: 1322-1327, 1984.

14.Houston, B. K. Psychophysiological responsivity and the Type A behavior pattern. Journal of Research in Personality, 17: 22-39, 1983.

15.Matthews, K. A., and Carra, J. Suppression of menstrual distress symptoms: A study of Type A behavior. Personality and Social Psychology Bulletin, 8: 146-ᄀ151, 1982.

16.Weidner, G., and Matthews, K. A. Reported physical symptoms elicited by unpredictable events and the Type A coronary-prone behavior pattern. Journal of Personality and Social Psychology, 36: 1213-1220, 1978.

17.Glass, D. C. Stress, behavior patterns and coronary disease. American Scientist, 65: 177-187, 1977.

18.Waldron, I., Hickey, A., McPherson, C., Butensky, A., Gruss, L., Overall, K., Schmader, A., and Wolmuth, D. Type A behavior pattern: Relationships to variation in blood pressure, parental characteristics, and academic and social activities of students. Journal of Human Stress, 6: 1626, 1980.
SAROV G., et al.

19. Mettlin, C. Occupational careers and the prevention of coronary-prone behavior. Social Science and Medicine, 10: 367-372, 1976.

20.Richards J.C., Hof A., Alvarenga M. Serum lipids and their relationships with hostility and angry affect and behaviors in men. Health Psychol. 19(4):393-8, 2000.

21.Camargo C.A. Jr., Vranizan K.M., Thoresen C.E., Wood P.D. Type A behavior pattern and alcohol intake in middle-aged men. Psychosom Med, 48(8): 575-81, 1986.

22.Lowell, E. L. The effect of need for achievement on learning and speed of performance. Journal of Psychology, 33: 31-40, 1952.

23.French, E. G. Effects of the interaction of motivation and feedback on task performance. In: J. W. Atkinson (Ed.), Motives in fantasy, action, and society. Princeton, NJ: Van Nostrand. 1958

24. De Charms, R., Morrison, H. W., Reitman, W., and Mcclelland, D. C. Behavioral correlates of directly and indirectly measured achievement motivation. In D. C. McClelland (Ed.), Studies in motivation. New York: Appleton-Century-Crofts, 1955.

25. McClelland, D. C. Risk taking in children with high and low need for achievement. In J. W. Atkinson (Ed.), Motives in fantasy, action, and society. Princeton, N. J.: Van Nostrand, 1958

26. Horner M.S. A psychological barrier to achievement in women. The motive to avoid success. In D.C. McClelland \& R.S. Steele (Eds) Human motivation\& A book of readings. Morristown, NJ: General Learning Press, 1973.

27. Horner, M. S. Sex differences in achievement motivation and performance in competitive and noncompetitive situations. Doctoral dissertation, University of Michigan, 1968.

28. Jackaway, R., and Teevan, R. Fear of failure and fear of success: Two dimensions of the, same motive. Sex Roles, 2: 283-293, 1976. 